\title{
HUMIC ACIDS - CATALYSTS REGENERATIVE REACTIONS OF MODELLING SYSTEMS
}

\section{Z.K. Kairbekov, Z.T. Eshova, E.A. Aubakirov, A.S. Daiynova, A.N. Alihanova, R.S. Bashirbaeva}

Change of redoks-potentials of modeling system Su (II, I) depending on the maintenance of fulvo - and humus the acids evolved from coal of the Kijaktisky deposit is investigated.

УДК 561.66

\section{ЖАНАЖОЛ КЕН ОРНЫ МҰНАЙЫН Со-ГУ/Ni-ҚАНҚАЛЫ КАТАЛИЗАТОРЫНДА ГИДРОӨНДЕУ}

\section{Ж.Қ. Қайырбеков, „Ж.К. Мылтықбаева, И.М. Джелдыбаева, Э.Т. Ермолдина, А.М. Калтаева \\ Әл-Фараби атындағы Қазақ ұлттық университеті}

Берілген жұмыста «Жанажсл» кен орны мұнайынан тура айдалыл алынган бензин фракциясының физикалық-химиялық қ̧асиеттері анықталып, оның сапасын Со-Гу/Ni-қ̧аңққалы катализаторында гидроөңдеу арқылы арттыру мүмкіндігі көрсетілді.

Соңғы жылдары дүние жүзінде мұнайды өңдеу өндірісі қайта құрылу кезеңінен өтіп жатыр. Бұл өз кезегінде индустриалды, сонымен қатар технологиялық көзқарастар жағынан жалғасын табуда. Мұнайды және мұнай өнімдерін пайдалану жылдан-жылға өсуде, сонымен қатар өңдеудің жалпы мөлшерінде мотор отындарының үлестері басым болады және қоршаған ортаны сақтаудың қалыпты актілері қатаңдатылады. Сондықтанда осы бағытта жүргізілетін зерттеулердің маңызы зор [1].

Бұл жұмыстың мақсаты мұнайды тікелей айдаудан алынған бензин фракциясының сапасын қаңқалы никель бетіне отырғызылған кобальт-гумат комплексі негізіндегі катализатор қатысында өңдеу арқылы арттыру болып табылады.

Жұмыстың зерттеу нысанына Жанажол кен орыны мұнайынан тура айдалып алынған бензин фракциясы алынды.

Мұнайды тікелей айдаудан алынған бензин фракциясы мен тауарлы отын ретінде қолданылатын бензин құрамдары әртүрлі болады. Себебі тауарлы бензин ретінде пайдалануға ұсынуға дейін отын әртүрлі химиялық өзгерістерге ұшырайды [2]. Сондықтан да мұнайды тікелей айдаудан алынған бензин фракциясының физика-химиялық қасиеттері анықталынды (1-кесте)

Жанажол кен орны мұнайынан тура айдалып алынған бензиннің физика-химиялық көрсеткіштері.

\begin{tabular}{|c|c|}
\hline Көрсеткіштері & Тура айдалған бензин \\
\hline Тығыздығы, $20{ }^{\circ} \mathrm{C}$, г/см3 & 0,7480 \\
\hline Сыну көрсеткіші, $\mathrm{n}_{\mathrm{d}}^{20}$ & 1,4721 \\
\hline Иод саны, г I2/100 г отын & 49,84 \\
\hline Күкірттің мөлшері, \% (масс.): & 0,5013 \\
\hline Фракциялық құрамы, ${ }^{\circ} \mathrm{C}:$ & \\
\hline Қайнаудың басталуы, ${ }^{\circ} \mathrm{C}$-дан төмен емес & 40 \\
\hline $10 \%$-ның айдалуы, ${ }^{\circ} \mathrm{C}$-дан көп емес & 51 \\
\hline 50 \%-ның айдалуы, ${ }^{\circ} \mathrm{C}$-дан көп емес & 77 \\
\hline $90 \%$-ның айдалуы, ${ }^{\circ} \mathrm{C}$-дан көп емес & 187 \\
\hline Қайнаудың соңы, ${ }^{\circ} \mathrm{C}$-дан көп емес & 190 \\
\hline Детонацияға тұрақтылығы: & \\
\hline Зерттеу әдісі бойынша октан саны & 49,404 \\
\hline Мотор әдісі бойынша октан саны & 55,945 \\
\hline Сыртқы түрі & ашық сары \\
\hline
\end{tabular}

Кестеден көрінгендей «Жанажол» кен орны мұнайынан тура айдалып алынған бензиннің тығыздығы 0,7480-ге, сыну көрсеткіші 1,4721-ке, йод саны 49,84, күкірттің мөлшері 0,5013, 
детонацияға тұрақтылығы: зерттеу әдісі бойынша октан саны 49,4-ке, мотор әдісі бойынша 55,9-ға тең.

Топтық анализ көмегімен сұйық өнімдер құрамындағы парафинді, ароматты, нафтенді көмірсутектер топтарына біріктіре отырып, жеңіл анықтауға болады. Бірақ бензин фракциясының құрамын топтық анализ көмегімен зерттеу жеткіліксіз. Сондықтан бензин фракциясының жекелеме көмірсутектік құрамы газды-храмотографиялық анализ арқылы анықталды

Мұнайдан алынған мотор отынының көмірсутектік-топтық құрамы

\begin{tabular}{|l|c|}
\hline Көмірсутектер & $\begin{array}{c}\text { Тура айдалған } \\
\text { бензин }\end{array}$ \\
\hline Октан саньг & 55,9 \\
\hline Парафиндер & 32,561 \\
\hline Изопарафиндер & 23,879 \\
\hline Ароматты к.с & 8,871 \\
\hline Нафтендер & 29,01 \\
\hline Олефиндер & 5,194 \\
\hline Циклоолефиндер & 0,485 \\
\hline
\end{tabular}

Бензиннің топтық көмірсутектік құрамының хромотографиялық анализ мәліметерінен көрінгендей, өнім қалыпты және изо-құрылымды парафинді көмірсутектерден $(32,45$ және 29,19 \%) тұрады. Сонымен қоса ароматты (28,19\%), олефинді $(0,66 \%)$ және нафтенді $(9,51 \%)$ көмірсутектерден құралған.

Келтірілген мәліметтерден зерттеуге алынған бензин фракциясының қазіргі заманғы талаптарға сай емес екендігін байқаймыз. Сондықтанда бензин фракцияларының құрамындағы көмірсутектерді тұрақтандыру мақсатында гидротазалау процесі қаңқалы никельге 2-7\% кобальтті сіңіру әдісімен отырғызылған катализатор қатысында, бөлме температурасында, атмосфералық қысымда каталитикалық «уткада» жүргізілді [3].

Таңдалынған катализаторда жүретін процестерді терең түсіну мақсатында Quanta 3D 200i Dual system FEI электронды микроскоп көмегімен (2-7\%) Co-Гу/Ni-қаңқалы катализаторларының электронды - микроскопиялық фотографиялары түсірілді.

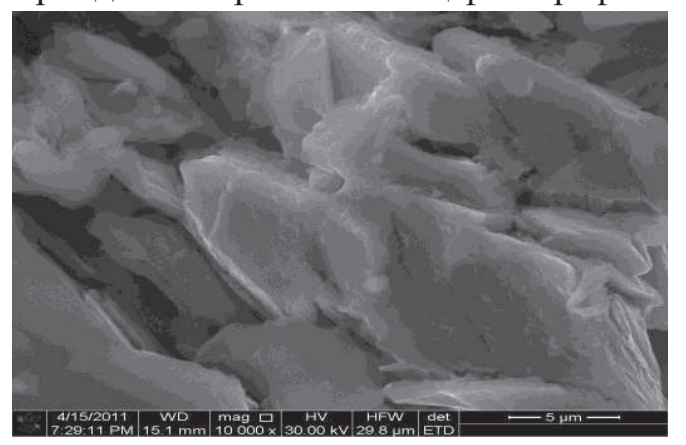

a) Ni-қаңқалы

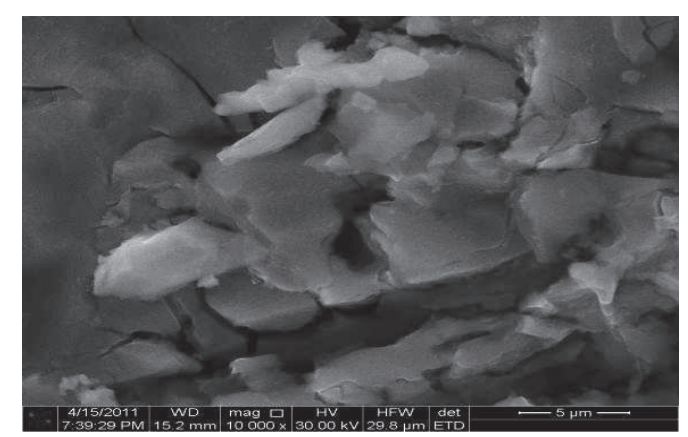

в) $5 \% \mathrm{Co}-Г \mathrm{y} / \mathrm{Ni}$-қаңқалы

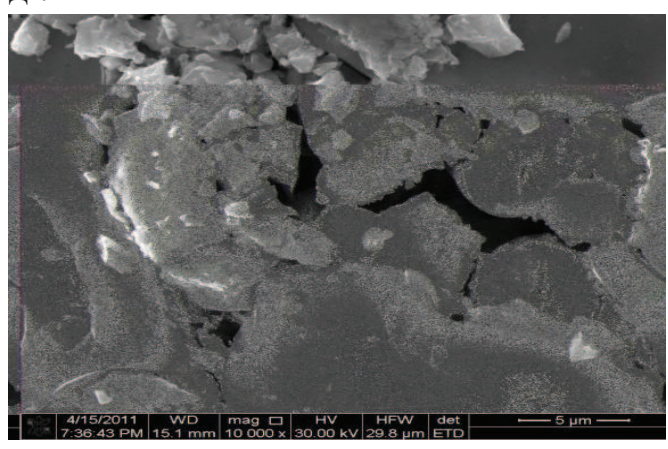

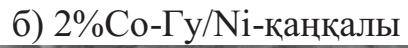

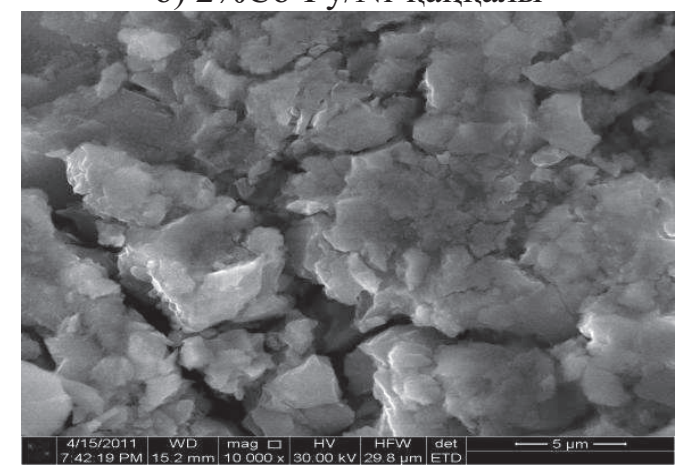

г) 7\% $\mathrm{Co}-Г$ - $\mathrm{Ni-қаңқалы}$

Катализаторлар үлгілерінің электронды микрофотографиялары

Суреттен көрінгендей, металл тасымалдағыш - қаңқалы никель әр түрлі пішінді агломераттар түрінде көрсетілген. Ал кобальтті отырғызғаннан кейін тасымалдағыш морфологиясы айтарлықтай 
өзгереді. Кобальт концентрациясын 2-7\% - ға жоғарылатқан сайын катализатор ірілене түсетіндігі байқалады, яғни кобальт концентрациясы жоғарылаған сайын (1б,в,г-суреттерден көрінгендей) тасымалдағыш бетінде әр түрлі пішінді агломераттар біркелкі таралған. Бұл жерден тасымалдағыш бетінде кобальт және гуматтың жинақталғандығын көруге болады.

Никель қаңқалы катализаторы бетінде гумат пен кобальт комплексінің тығыз жабысқан моноқабаты түзіледі. Біздің ойымызша, диффузиялық факторлардың әсер ету есебінен кобальт концентрациясымен (тасымалдағыш бетін) модифицирлеу катализатор активтілігінің төмендеуіне алып келеді [4].

Бұл өз кезегінде, гидротазалау процесінде де айқын көрінеді. Мәселен, 2\%Co-Гу/Ni-қаңқалы катализаторында гидрленген «Жанажол» кен орны мұнайынан тура айдалып алынған бензин фракциясында күкірт мөлшері 7\%Co-Гу/Ni-қаңқалы катализаторында гидрленген бензин фракциясымен салыстырғанда, сәйкесінше 0,4713-тен 0,3317-ке дейін төмендеген. Ал бастапқы бензин фракциясымен салыстырғанда октан саны зерттеу әдісі бойынша 51,6-дан 57,1-ге, яғни 6 бірлікке жоғарылағандығын айқындай түседі. Ол бензин фракциясының жекелеме көмірсутектік құрамын газды-храмотографиялық анализ арқылы зерттеліп, дәлелденді.

«Жанажол» кен орыны мұнайынан тура айдалып алынған және 2\%Сo-Гу/Ni-қаңқалы катализаторында гидроөңделген бензин фракциясының көмірсутектік-топтық құрамы

\begin{tabular}{|l|c|c|}
\hline Көмірсутектер & Тура айдалған бензин & Гидроөңделген \\
\hline Парафин & 17,243 & 14,337 \\
\hline Изопарафин & 41,952 & 53,453 \\
\hline Нафтен & 25,159 & 13,352 \\
\hline Ароматты & 9,886 & 14,987 \\
\hline Олефин & 5,760 & 3,871 \\
\hline Октан саны & & \\
Мотор әдісі бойынша & 45,6 & 50,3 \\
Зерттеу әдісі бойынша & 51,6 & 57,1 \\
\hline
\end{tabular}

Кестеден көрінгендей, Жанажол кен орынынан тура айдалған бензин фракциясының құрамы 2\%Co-Гу/Ni-қаңқалы катализаторында гидрогендегеннен кейін үлкен өзгеріске ұшырайды [5]. Алынған бензин құрамында парафиндер мөлшері отырғызылған Co-Гу/Ni-қаңқалы катализаторында 17,243\%-дан 14,337\%-ға кеміген. Оның ішінде бутан екі есеге дейін (0,0059-дан 0,0022\%-ға), нонан (3,503-тен 1,413\%-ға дейін), декан мөлшері (2,312-тен 0,369\%-ға) және октан (4,423-ден 3,452\%-ға дейін) төмендеген. Яғни, Co-Гy/Ni-Re катализаторында гидрокрекинг, изомеризация, циклизация реакциялары жүреді. Гидроөңделген бензинде бастапқы бензин құрамында кездеспеген 2,2,3триметилпентан, $(0,032 \%)$ 2,3,3-триметилпентан $(0,392 \%), 2,2,3$-триметилгексан $(1,606 \%), \quad 3,3$ диметилгептан $(1,854)$, 2-метил 4-этил гексан $(0,854 \%), 3$-метилоктан $(1,401 \%)$ және т.б. көмірсутектер пайда болған. Кейбір изопарафиндердің мөлшері - 3,3-диметилпентан 0,1291-ден 1,766\%-ға дейін 14 есеге, 3-этилпентан 0,30-ден 3,289\%-ға дейін 10 есеге, 2-метилгексан 1,753\%-дан 2,538\%-ға, 2,5-диметилгексан 0,378-тен 1,321\%-ға 5 есеге дейін артқан. Нафтенді көмірсутектер бастапқы бензинде 25,159\% болса, Со-Гу/Ni-қаңқалы катализаторында гидроөңдегеннен кейін 13,352\%-ды құрайды. Гидроөңдеу процесінде алкилароматты көмірсутектердің дезалкилденуі нәтижесінде ароматты көмірсутектердің мөлшері (9,886-дан 14,987\%-ға дейін) 1,5 есеге артады. Бастапқы бензиннің октан санымен салыстырғанда мотор әдісі бойынша - 45,6, зерттеу әдісі бойынша - 51,6 тең болса, ал 2\%Co-Гу/Ni-қаңқалы катализаторында гидроөңделген бензиннің октан саны сәйкесінше 50,3-ке және 57,1-ге жоғарылайды. Гидроөңдеуден кейін күкірт мөлшері бастапқымен салыстырғанда 0,250\%-дан 0,023\%-ға дейін кеміген. Қорыта келгенде бұл қазіргі кезде мотор отынына қойылатын талапты қанағатттандырады, европалық стандартқа сәйкес келеді.

\section{Әдебиеттер}

1. В.С.Азев, С.Р.Лебедев, Т.Н.Митусова, В.Е.Емельянов. Улучшение качества автомобильных бензинов и дизельных топлив // Химия и технология топлив и масел.- 1998. - №5. - с. 5-8.

2. Мановян А.К. «Технология первичной переработки нефти и природного газа».Москва «Химия»,2001г.

3. Қайырбеков Ж.Қ., Аубакиров Е.А., Мылтықбаева Ж.К., Джелдыбаева И.М. Мұнайдан және көмірден алыгған бензин фракциясына Мо-Гу/Ni-Реней катализаторының әсері // Сегізінші халықаралық ғылыми 
Надіров оқулары «Мұнай-газ кешенінің ғылыми технологиялық дамуы» Алматы, 16-17 қыркүйек 2010 ж. Б.138143

4. Квентин Дебюишер, Жан-Люк Нокка. Промышленные показатели технологии обессеривания Рrime$\mathrm{G}+{ }^{\mathrm{TM}}$ бензина каталитического крекинга // Нефтепереработка и нефтехимия. - 2003.- №9 - c.3-12

5. Мылтықбаева Ж.К. Қаражыра көмірінен каталитикалық гидрогендеу арқылы мотор отындарын алу технологиясы және алынған сұйық өнімдердің сапасын арттыру: дис. хим. ғылым. наук. -Алматы, 2006. -118 бб.

\title{
ГИДРОПЕРЕРАБОТКА НЕФТИ МЕСТОРОЖДЕНИЯ ЖАНАЖОЛ НА Со-Гу/Ni-скелетных КАТАЛИЗАТОРАХ
}

\section{Ж.К. Каирбеков, Ж.К.Мылтыкбаева, И.М. Джелдыбаева, Э.Т. Ермолдина, А.М. Калтаева.}

В работе были определены физико-химические свойства прямогонных бензиновых фракции из нефти месторождения Жанажол. Показано возможность повышения качество бензина путем гидропереработки на Co-Гу/Ni-скелетных катализаторах.

\section{HYDROTREATING OF ZHANGAZHOL CRUDE OIL IN CATALYSIS OF Co-Gu/Ni-SKELETON}

\author{
Zh.K.Kairbekov, Zh.K.Myltykbaeva, I.M.Dzheldybaeva, E.T.Yermoldina, A.M.Kaltaeva.
}

In this article determination of physico-chemical properties of benzene produced from Zhangazhol crude oil by straight distillation. Aim of improving quality of them hydrotreating in catalysis of Co-Gu/Ni-skeleton are investigated.

ӘОЖ 547.592:665.77

\section{КОКСОХИМИЯЛЫҚ ШАЙЫРДАН МОТОР ОТЫНДАРЫН АЛУ}

\author{
Ж.Қ. Қайырбеков, Н.Т. Смағұлова, Т.Ш. Досмайл
}

\section{Әл-Фараби атындағы Қазақ ұлттық университеті, nazym.smagulova.@mail.ru}

Шұбаркөл кен орнының тас көмірін жартылай кокстеуден алынван біріншілік шайырдың физикахимиялық көрсеткіштері, жеке көмірсутектік құрамы анықталды. Төменгі қ̧ысылда коксохимияльққ шайырды суспензирленген Мо-құрамды катализаторында байытып және одан әрі шывымы жовары, сапальь мотор отынын алу арқылы шайырды өңдеудің жаңа концепциясы жасалды.

Коксохимиялық шайырдың органикалық массасы ароматты табиғаты бар жоғары молекулалы қосылыстардан және гетероатомдардан құралған асфальтенге айналуы сұйылтудың бастапқы сатысы болып табылады. Бұл кезде түзілген радикалды фрагменттер полимерленуі немесе сутекті қосып алып тұрақты өнімдерге айналуы мүмкін. Бұл жағдайда процестің селективтілігі катализатор табиғатымен анықталады. Гидрлеуші активтілік танытатын катализаторлар жеңіл көмірсутектердің түзілу реакциясын тездетеді. Қышқылдық типтегі катализаторлар жоғары молекулалы өнімдердің түзілуіне әкелетін қосымша полимерлену, поликонденсирлену реакцияларының жүруіне ықпал етеді. Катализдік гидрогендеу технологиясындағы кемшіліктердің бірі мұнай өңдеу өндірістерінде құны қымбат катализаторларды қолдану болып табылады. Сондықтанда мұнай және мұнай өнімдерін, көмірді өңдеу процестерінде қолданылатын дәстүрлі гетерогендік катализаторлардың орынына псевдогомогенді катализаторларды пайдалану көмірсутектік шикізатты мотор отындарына және химиялық өнімдерге өңдеу технологиясының эффективтілігін арттырады.

Көмірден химиялық өнімдер алуда деструктивті термиялық процестер қолданылады. Мұндай термиялық процестерге кокстеу және жартылай кокстеу жатады. Коксохимиялық шайыр негізінен конденсирленген ароматты көмірсутектерден және басқа да жоғары молекулалы қосылыстардан құралғандықтан ауыр өңделетін шикізат көзіне жатады. Коксохимиялық шайырды өндірісте алдымен шайырды сусыздандырып, жеке фракцияларға бөліп, алынған фракцияларды сілтілік, қышқылдық экстракция, кристаллизация, гидротазалау әдістерін қолдану арқылы бензол, нафталин, фенол, пиридинді негіздер және басқада химиялық өнімдер алады. Коксохимиялық шайырдан химиялық өнімдер алудың әрбір сатысы көп мөлшерде реагенттердің шығындалуына, жылудың жұмсалуына және құнды өнімдердің жоғалуына әкеледі.

Қазіргі таңда шикізатқа қойылатын талаптың артуынан коксохимиялық шайырды гидротазалау 